\title{
ゲル化剤に見る自己組織化現象
}

\section{Self-Organization of Gelators}

英謙二・白井汪 芳

\section{1.はじめに}

最近、水や有機溶媒を物理的にゲル化(固化)することの できる低分子化合物が報告されている。このような化合物 はゲル化骫と呼ばれ、超分子化学の見地に立った学問的興 味としてのみでなく、製品に応用しようという実用面でも 注目を集めている11。例えば、12-ヒドロキシステアリン 酸は食用油を固める性質があり、廃油固化剛として実用化 されている。その他にも有機溶媒をゲル化できる低分子化 合物として、1，3；2，4-ジベンジリデン-D-ソルビトール が制汗商品の原料として、N-ラウロイル-L-グルタミン酸$\alpha, \gamma$-ビス-n-ブチルアミドは流出油処理剤として実用化さ れている。さらに、芳香族ジウレアは潤滑油グリースの原 料である。2-エチルヘキサン酸アルミニウムは炭化水素系 溶凨に室温で溶解しゲル様の粘稠物を形成するのでインキ の増粘剤として利用されている。本稿では分子レベルで起 こるゲル化剈の自己組織化現象とそれによってもたらされ
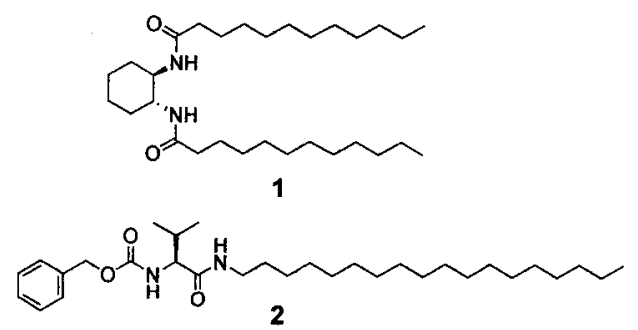<smiles>CC(C)CCCC(C)CC1NC(N)=N[C@@H]1N</smiles>

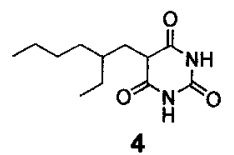

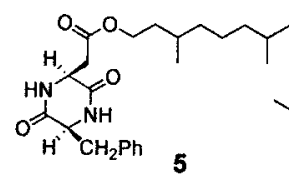

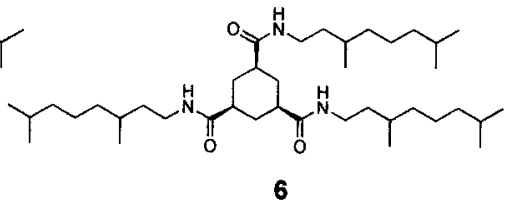



KENJI HANABUSA

信州大学大学院総合工学系研究科 教授 工学博士

干 $386-8567$ 上田市常田 3-15-1 Tel : 0268-21-5487

E-mail : hanaken@giptc.shinshu-u.ac.jp 〈専門〉超高分子化学、高分子化学
る巨視的なゲル化という現象について述べる。

\section{2. ゲルの形成}

低分子ゲル化骫によるゲル形成の実際の手順を図 1 に示 す。ゲルの作製はきわめて簢単である。例えば(a)ゲル化

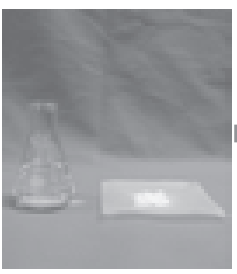

(a)

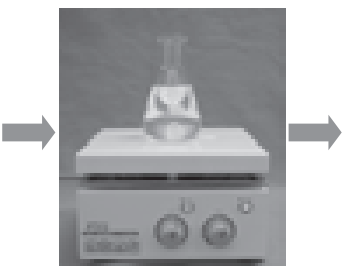

(b)

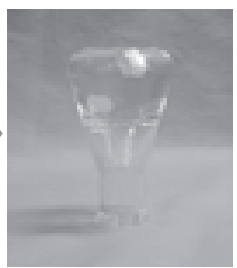

(c)
図 1 ゲル化剤による溶媒のゲル化過程

剤を溶媒に加え(この写真では $1.5 \mathrm{~g}$ の後述のゲル化剤 1 と $100 \mathrm{~mL}$ のトルエン)、(b)一旦加熱溶解させ、その後室温 に戻す。すると、放冷過程で簡単にゲル化して (c)のよう にゲルが形成される。なお、形成されるゲルの外見はゲル 化剤の構造と溶媒の種類に依存して透明、半透明、不透明 である。溶剤に添加すると室温で溶け自然にゲル化すると いう一部のゲル化骫を除き、ゲル化骫によるゲル形成の過 程は基本的には図 1 のようにまず加熱溶解させ、その後に 放冷してゲル化させるという手順をとる。

\section{3. ゲル化と結晶化の類似性}

低分子化合物によるゲル化の挙動を結晶化と比較して示 すと図 2 のようになる。ミョウバンのような結晶を水中で 加熱すると溶けて均一溶液となる。これを冷やすと溶解度 の差に相当するミョウバンの結晶が析出する(図 2 の左半 分)。しかし、まれに結晶化の代わりにゲル化する場合が あり(図 2 の右半分)、これが本稿のテーマである。析出し た結晶を加熱すると再溶解するように、生成したゲルを加

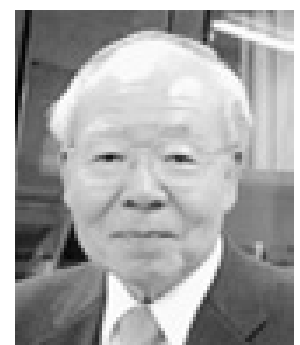

HIROFUSA SHIRAI

信州大学教授·理事工学博士

干 386-8567 上田市常田 3-15-1

Tel : 0268-21-5485

E-mail : hshirai@giptc.shinshu-u.ac.jp

〈専門〉機能性高分子 


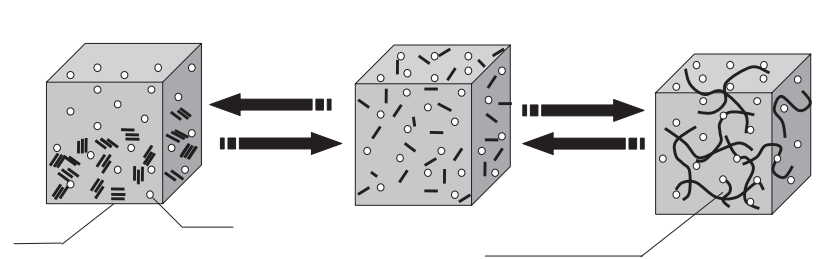

図 2 低分子化合物の挙動

熱すると元の均一溶液に戻る。左半分の結晶化は分子が分 子間相互作用により三次元的に秩序性のある配列をするた めに溶媒から相分離する現象であり、右半分のゲル化は 2 次元的な配列で繊維状の会合体が網目構造を形成しその空 隙に溶媒を絡めこむために惹起される。結晶化もゲル化も 原動力は共に水素結合やファンデルワールスカなどの非共 有結合的相互作用である。しかし、結晶化は究極の安定状 態であるけれども、ゲル化は結晶化に至る前の準安定状態 である。

なお、放冷後にゲルではなくミセルやベシクル、リオト ロッピク液晶などの会合体を形成する場合があるが、それ らの自己組織化現象については本稿ではふれない。

\section{4. ゲル化剤の自己組織化}

化合物 1 6 は筆者らが開発した代表的ゲル化剛、増粘 骫である。化合物 1～6 は図 3 に示すような分子間水素結 合を基本構造として溶媒中で自己組織化し、その結果ゲル 化あるいは増粘化する。

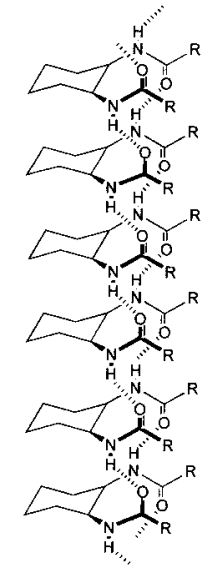

(a)

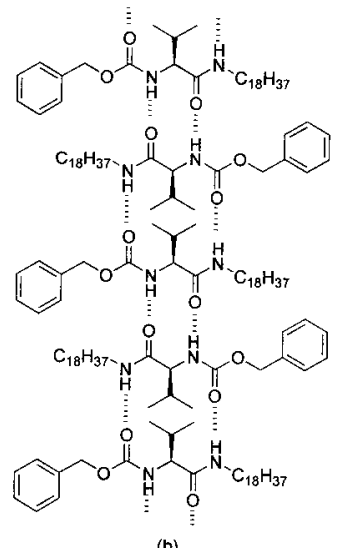

(b)

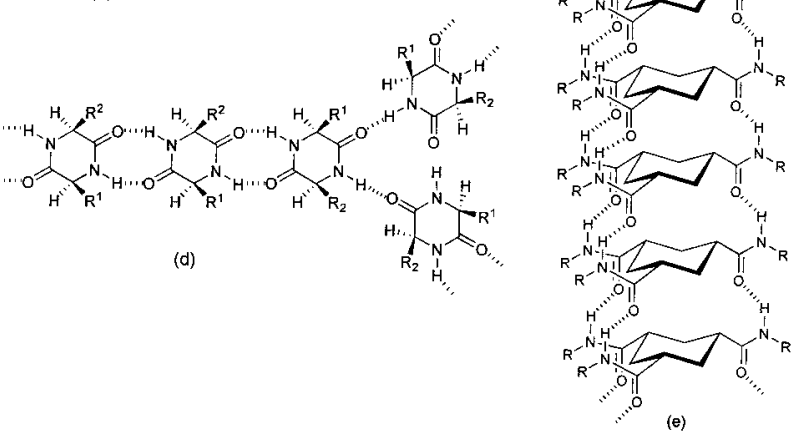

図 3 ゲル化剤1～6の形成する分子間水素結合のパターン

\section{1 シクロヘキサンジァミン誘導体}

trans-1,2-ジアミノシクロヘキサンのジアミド誘導体 1

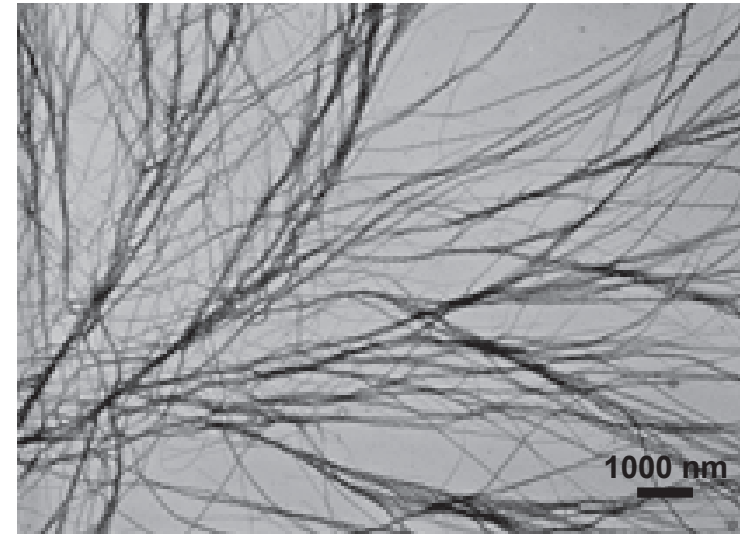

図４１のアセトニトリル希薄ゲルの TEM 写真

は、炭化水素、各種アルコール、ケトン、エステル、DMF、 DMSO、四塩化炭素、芳香族化合物、鉱物油、植物油、 シリコンオイルなど広範囲の溶剤や油をゲル化できる2)。 1 のゲルの透過型電子顕微鏡観察では、繊維状のらせん会 合体が見られた(図 4)。trans-(1R,2R)から合成した 1 では 左巻きのらせん会合体が形成され、鏡像異性体の trans $^{-}$(1S, 2S)から合成した 1 では右巻きのらせん会合体が観察され た。X線構造解析から、1 1 非対称な分子間水素結合(図 3 a)を作るためアルキル基のついている片側が立体的にこみ あって会合体が曲がり、その結果らせん状会合体に成長す る。分子レベルでの不斉が分子集合体の不斉を決定してい ることになる。また、1のみを加熱溶融させ $168^{\circ} \mathrm{C}$ でアニー リングすると光学顕微鏡で観察できる数 $\mu \mathrm{m}$ サイズの超巨 大らせん状会合体（図 5)に成長する。この場合も trans-(1R, 2R) から合成した 1 では左巻きの巨大らせん会合体である。

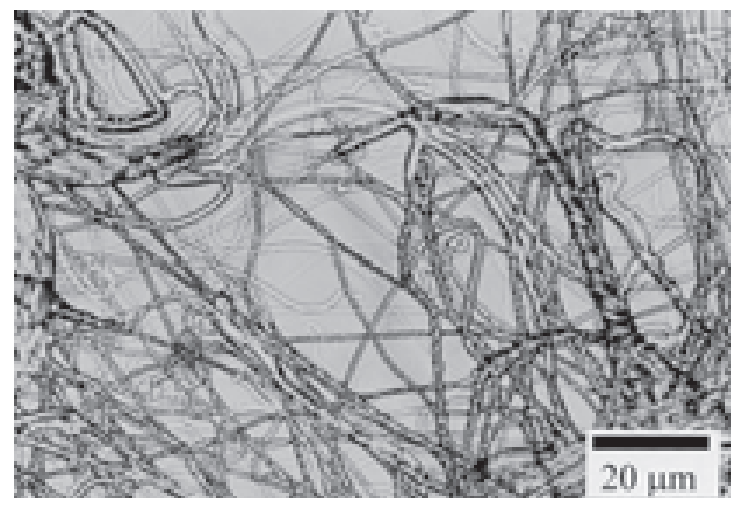

図 51 が形成する巨大らせん状会合体の光学顕微鏡写真

なお、1,2-シクロヘキサンジアミンには絶対配置が (1R, 2R) と $(1 \mathrm{~S}, 2 \mathrm{~S})$ の 2 つのランス体のほかにシス体の合計 3 個の異性体がある。この中でシス体から合成した 1 に相 当するジアミド誘導体にはゲル化能力はない。また $1,3-シ$ クロヘキサンジアミンや 1,4-シクロヘキサンジアミンから 合成した化合物にもゲル化能はない。分子模型を組むと、 トランス体の 2 つ置換基はともにエクアトリアル位にあ り図3aのうな分子間水素結合による分子集合体の形成 が可能であるけれども、シス体の場合は 2 つの置換基がア 
キシャル位とエクアトリアル位にあるため分子間水素結合 は作れない。これがシス体にはゲル化能力がない理由であ る。なお、ラセミ体 ( (1R, 2R) と $(1 \mathrm{~S}, 2 \mathrm{~S})$ の等モル混合物 $)$ の1は結晶性がよくゲル化能はない。

\section{2 アミノ酸誘導体}

筆者らは $\mathrm{N}-$ ベンジロキシカルボニル-L-バリン誘導体 2 などの一連のアミノ酸誘導体 ${ }^{3}$ に強いゲル化能があること を見つけた。2 は 1 と同様に極性溶媒から非極性溶媒まで のさまざまな溶媒や油を固化することが可能な優れたゲル 化剂である。ゲル化はアミド結合やウレタン結合の分子間 水素結合(図 $3 \mathrm{~b}$ ) や長鎖アルキル基のファンデアワールス 力などを主な駆動力とすることがわかっている。なお、2

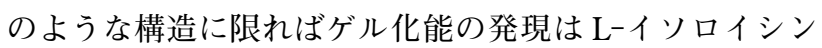
残基や $\mathrm{L}$-バリン残基に特有であり、他のアミノ酸誘導体 にはゲル化能はない。また、ラセミ体にはゲル化能はみら れない。2の四塩化炭素ゲルの透過型電子顕微鏡写真を図 6 に示す。幅が数 $10 \mathrm{~nm}$ サイズの繊維状会合体が多数形成 されている。

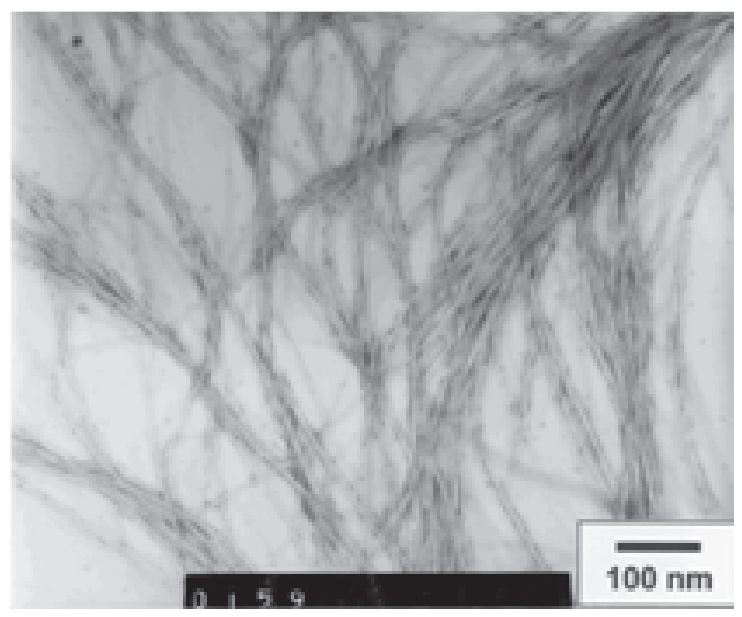

図 62 の四塭化炭素希薄ゲルの TEM 写真

アミノ酸誘導体によるゲル化の主な原動力は分子間水素 結合の形成である。図 7 に-ベンジロキシカルボニルー $\mathrm{L}-$ イロイシンオクタデシルアミド $(2$ の $\mathrm{L}-$ バリン残基が L-イソロイシン残基に置き換わった化合物)のシクロヘキ サンゲルとクロロホルム溶液の FT-IR スペクトルを示す。 $\mathrm{N}$-ベンジロキシカルボニル-L-イソロイシンオクタデシル アミドのシクロヘキサンゲルの FT-IR スペクトルは NH 伸 縮振動が $3294 \mathrm{~cm}^{-1}$ に、ウレタンの $\mathrm{C}=\mathrm{O}$ 伸縮振動が 1689 $\mathrm{cm}^{-1}$ に、アミドの伸縮振動が $1645 \mathrm{~cm}^{-1}$ にあらわれウレタ ン結合とアミド結合の $\mathrm{NH}$ と $\mathrm{C}=\mathrm{O}$ 間で水素結合が形成さ れており、非水素結合型の $\mathrm{NH}$ や $\mathrm{C}=\mathrm{O}$ はほとんど存在し ない。一方、ゲル化できないクロロホルム溶液ではクロロ

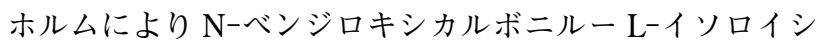
ンオクタデシルアミドは溶媒和されるため、 $\mathrm{NH}$ 伸縮振動 が $3437 \mathrm{~cm}^{-1}$ に、ウレタンの $\mathrm{C}=\mathrm{O}$ 伸縮振動が $1714 \mathrm{~cm}^{-1}$ に、 アミドの伸縮振動が $1669 \mathrm{~cm}^{-1}$ にあらわれクロロホルム分 子に溶媒和され非水素結合型である。

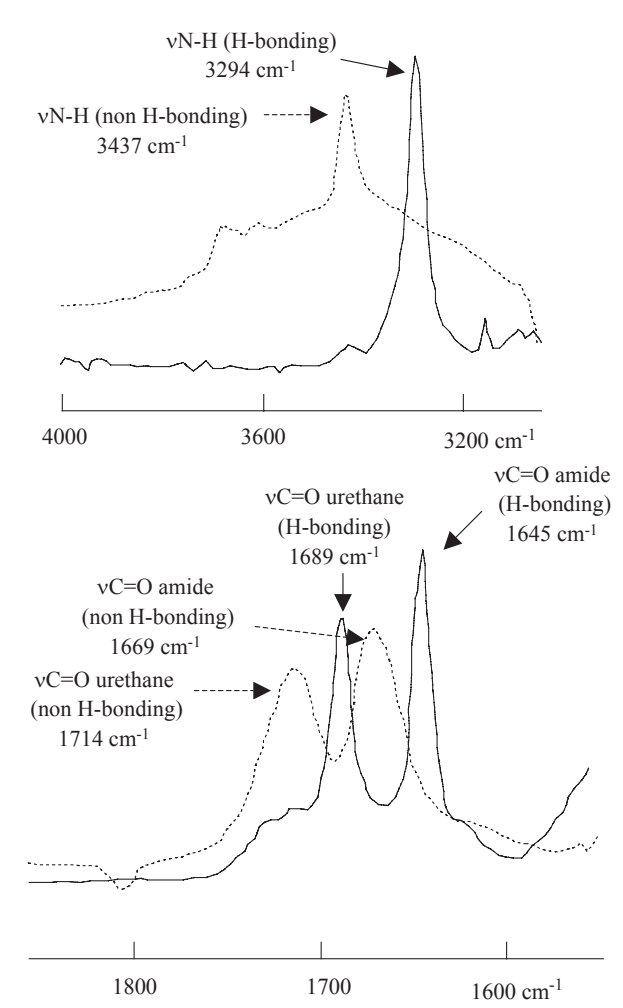

図 7 N-ベンジロキシカルボニル-L-イソロイシンオクタ デシルアミドのシクロヘキサンゲル(実線 $\left.; 6 \mathrm{~g} \mathrm{~L}^{-1}\right)$ とクロロホルム溶液(破線; $6 \mathrm{~g} \mathrm{~L}^{-1}$ )の FT-IRスペク トル

筆者はアミノ酸系化合物によるゲル化の機構を次のよう に考えている。アミド、ウレタンセグメントの分子間水素 結合により会合体を形成し、それが巨大会合体へと成長す る。続いてファンデルワールスカなどの相互作用によりそ れらが束になって網目状に絡まり相互に運動を妨げあって 流動性を失い、その中に溶媒を抱き込んでゲル化が起こる。

筆者は低分子ゲル化剛の開発のためには、以下の 3 つの 要素を分子設計に盛り込む必要があると考えている。

(a) 水素結合などの分子間相互作用による巨大䋊維状会合 体の形成

（b）ファンデルワールスカなどによる繊維状会合体間の結 合・三次元化

(c) 準安定状態であるゲルを安定化させ結晶化を妨げる要 因を有すること

\section{3 二成分型ゲル化剤}

等モルの 3 と 4 とから成る二成分型ゲル化剂は図 $3 \mathrm{c}$ の アレイ型の相補的分子間水素結合によって繊維状会合体を 形成する ${ }^{4)}$ 。一般に一成分型のゲル化剂の場合は、一旦溶 媒に溶解させないといけないので加熱という操作が不可欠 であるが、二成分型ゲル化剤の場合は各成分が溶媒に易溶 であれば加えるだけで個々の成分が溶解し 2 分子間で自己 組織化が抗こりゲル化することになる。例えば、等モル量 の 3 と 4 をクロロホルムに加え放置すると室温で自然溶 解しゲル化する。酢酸エチル中で 3 と 4 の形成する繊維 状会合体の透過型電子顕微鏡写真を図 8 に示す。ところど 


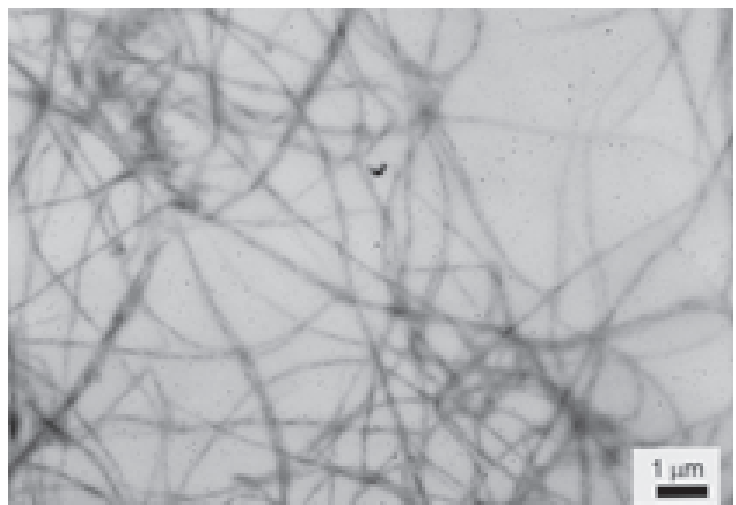

図 83 と 4 の等モル混合物から作った酢酸エチル希薄ゲ ルの TEM 写真

ころに無数のくびれが見えるが、このくびれは相補的分子 間水素結合によって形成されたテープ状会合体が抳れ、く びれたリボン状会合体になったものと考えられる。

\section{4 環状ジペプチド誘導体}

上述のように低分子ゲル化剤の開発のためには、(a)水 素結合などの分子間相互作用による巨大繊維状会合体の形 成、(b)ファンデルワールス力などによる䋊維状会合体間 の結合・三次元化、(c) 準安定状態であるゲルを安定化さ せ結晶化を妨げる要因を有することの 3 条件を満たす化合 物を見つける必要がある。

上記のゲル化剤としての必要条件 $(\mathrm{a})$ ～(c) を満たす化合 物として環状ジペプチド誘導体が考えられる。環状ジペプ チド (2、5-ジケトピペラジン誘導体) は 6 員環構造をして おり 2 個のアミド結合があるため、図 $3 \mathrm{~d}$ のように分子間 水素結合を通して条件(a)の分子集合体を形成すると考え られる。また水素結合に欠陥点が生じれば(b)の繊維状会 合体の三次元化をひきおこすであろう。そして $\mathrm{R}^{1}$ 基と $\mathrm{R}^{2}$ 基のランダム配列は結晶化を妨げ、ゲル状態が安定化され (c)を満たすことになる。

実際、環状ジペプチド誘導体の中にはゲル化能を有する ものがある5)。同一のアミノ酸成分からなる環状ジペプチ ド誘導体はすべて結晶性がよくゲル化能は見られないが、

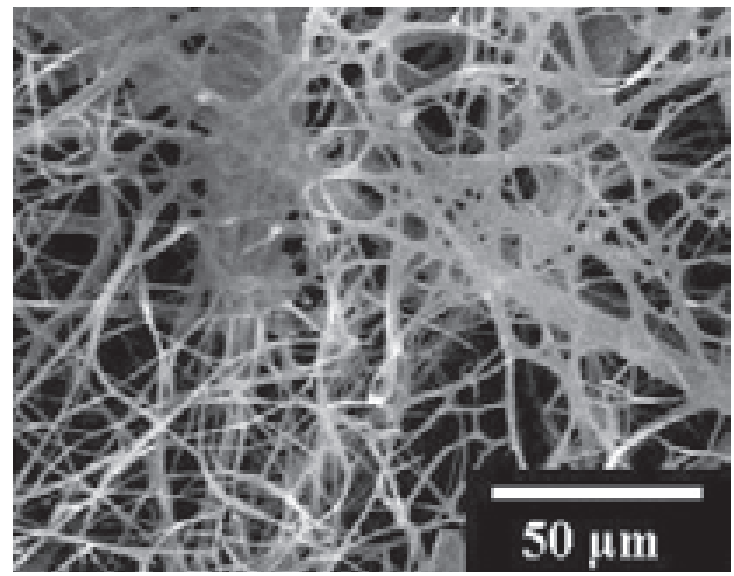

図 9 1-メチル-4-ブチルイミダゾリウム三フッ化ホウ素 塩の中で形成された 5 の繊維状会合体の SEM 写真
L-バリン、L-ロイシン、L-フェニルアラニンのような中 性アミノ酸と $\mathrm{L}-$ グルタミン酸- $\gamma$-エステル、 $\mathrm{L}-$ エスパラギ ン酸- $\beta$-エステルのような酸性アミノ酸という性質の異な る二つのアミノ酸を組合わせた環状ジペプチドはゲル化剤 として作用する。中でも、人工甘味料のアスパルテーム ${ }^{\circledR}$ を原料として合成した化合物 5 はアルコール・エステル・ ケトン・芳香族化合物・ダイズ油・グリセリド、デカメチ ルシクロペンタシロキサンなどをゲル化する。また、ゲル 化剂 5 は様々なイオン性液体をゲル化できる特徴がある ${ }^{6)}$ 。 図 9 はイオン性液体の 1-メチル-4-ブチルイミダゾリウム 三フッ化ホウ素塩の中で形成された 5 の繊維状会合体の SEM 写真である。

\section{5 cis-1,3,5-シクロヘキサントリカルボキサミド誘導体} cis-1,3,5-シクロヘキサントリカルボキサミド誘導体 6 は四塩化炭素、シクロへキサン、ベンゼン、ピリジンなど に加えて加熱溶解後、放冷するとゲル化の代わりに増粘化 を惹き起こす7,8)。たとえば、6の四塩化炭素溶液 $\left(5 \mathrm{~g} \mathrm{~L}^{-1}\right)$ は $25^{\circ} \mathrm{C}$ で $2,700 \mathrm{cP}$ の粘性を示す。6 は分子内に 3 個のア ミド結合を有するため分子間水素結合により高分子様の超 分子を形成する(図 $3 \mathrm{e}$ )。汎用高分子による増粘はその巨 大な分子長に起因するので電子顕微鏡観察してもその像 (高分子鎖の 1 本ずつ) は捕まえることはできない。一方、 低分子化合物による増粘現象は高分子様の超分子集合体の 形成に起因するので、電子顕微鏡観察でその超分子集合体 を見ることができる。困 10 は 6 の四塩化炭素溶液中で形 成される会合体の TEM 像である。この像では小さなもの でも幅が $100 \mathrm{~nm}$ 以上あるので、電子顕微鏡で観察される 超分子集合体は図 $3 \mathrm{e}$ に示したような分子レベルの集合体 ではなく、分子レベルの集合体が無数に集合を繰り返した 後の超巨大会合体であると考えられる。



図10 6 の四塩化炭素増粘溶液の SEM 写真

\section{5. おわりに}

低分子化合物によるゲル化の興味深い点は目では見えな いミクロな分子レベルでの自己組織化が、ゲル化というマ クロな巨視的現象につながることである。言い方を变える と低分子化合物がゲル化を惹起するときは、必ず分子の自 
己組織化によって三次元網目構造が形成される。しかし、 結晶化もまた究極の分子の自己組織化であり、結晶ではな く準安定状態のゲルを形成する低分子化合物すなわちゲル 化剂を分子設計する指針は未だにない。それこそが筆者ら をゲル化浏の研究に惹き付けてやまない理由なのである。

\section{参考文献}

1) (a)P. Terech, R. G. Weiss, Chem. Rev. 97, 3133(1997); (b) J. H. Esch, B. L. Feringa, Angew. Chem. Int. Ed. 39, $2263(2000)$; (c) L. A. Estroff and A. D.Hamilton, Chem. Rev. 104, 1201 (2004).

2) K. Hanabusa, M. Yamada, M. Kimura and H. Shirai, Angew. Chem. Int. Ed. Engl., 35, 1949(1996).

3) (a) K. Hanabusa, K. Hiratsuka, M. Kimura and H. Shirai,
Chem. Mater., 11, 649 (1999); (b) K. Hanabusa, J. Tange, Y. Taguchi, T. Koyama and H. Shirai, Chem. Commun., 390 (1993).

4) K. Hanabusa, T. Miki, Y. Taguchi, T. Koyama and H. Shirai, Chem. Commun., 1382(1993).

5) K. Hanabusa, M. Matsumoto, M. Kimura, A. Kakehi and H. Shirai, J. Colloid Interface Sci., 224, 231 (2000).

6) K. Hanabusa, H. Fukui, M. Suzuki and H. Shirai, Langmuir, 21, 10383(2005).

7) K. Hanabusa, A. Kawakami, M. Kimura and H. Shirai, Chem. Lett., 191(1997).

8) A. Sakamoto, D. Ogata, T. Shikata and K. Hanabusa, Macromolecules, 38, 8983(2005).

\section{平成 18 年度}

\section{第19回におい・かおり環境学会研究発表会}

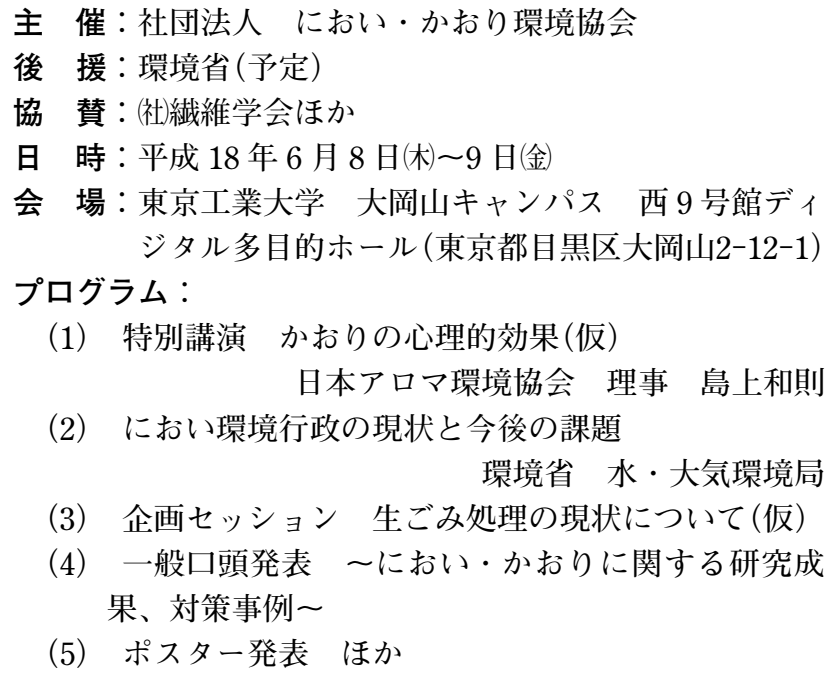

（1）特別講演 かおりの心理的効果(仮) 日本アロマ環境協会 理事 島上和則

（2）におい環境行政の現状と今後の課題 環境省 水·大気環境局

（3）企画セッション 生ごみ処理の現状について(仮)

（4）一般口頭発表 〜におい・かおりに関する研究成 果、対策事例

（5） ポスター発表 ほか

連絡先：(社)に打い・か打り環境協会(担当：重岡、小川、 中过)

干101-0031 東京都千代田区東神田 2-6-2

TEL : 03-5835-0315 FAX : 03-5835-0316

E-mail : info@orea.or.jp http ://www.orea.or.jp (5 月にプログラムを掲載)

\section{6 年 TES 試験の実施要項}

試験日：平成 18 年 7 月 16 日(日)

日 程：4月 1 日：要項発表 5月10日～5月20日：出願 の受付期間 7 月16日：試験日 11月 1日：登録 日

試験会場(予定)：

札幌: 北海道浅井学園大学 北方圈学術情報センター 札幌市中央区南 1 条西 22 丁目 1-1

東京：文化女子大学 東京都渋谷区代々木 3-22-1

名古屋：椙山女学園大学 愛知県名古屋市千種区星が丘 元町 17-3

関西：武庫川女子大学 兵庫県西宮市池開町 6-46

福井: 福井市民福祉会館 福井県福井市春山 2-7-15

倉敷：倉敷ファッションセンター 岡山県倉敷市児島駅 前 1-46

受験資格：学歴、年齢を問わず誰でも受験可能。

手数料:

受験料 [A] 13,650 円〔今年初めて受験する人〕

受験料 [B] 10,500 円〔継続受験の人〕

免除判定申請料 6,300 円

登録料 11,550 円

願書の申込・問合先 :

社団法人 日本衣料管理協会

干105-0011 東京都港区芝公園 2-11-13-205

TEL : 03-3437-6416 FAX : 03-3437-3194

E-mail : jasta @mtb.biglobe.ne.jp http : //www.tesshikaku.jp (TESの HP) http : //www.jasta 1.or.jp（協会 の $\mathrm{HP}$ ) 